\title{
RUCHY PROTESTU JAKO PRZYKŁAD ASERTYWNEJ KULTURY OBYWATELSKIEJ. PRZYPADEK OGÓLNOPOLSKIEGO STRAJKU KOBIET
}

\author{
PROTEST MOVEMENTS AS AN EXAMPLE \\ OF ASSERTIVE CIVIC CULTURE: \\ THE CASE OF POLISH WOMEN'S STRIKE
}

Agnieszka Ziętek* 우

\begin{abstract}
ABSTRAKT
Kategoria kultury obywatelskiej stanowi jedno z pojęć służących do opisu współczesnej rzeczywistości społeczno-politycznej. W ujęciu klasycznym (civic culture) jest ona definiowana jako kombinacja trzech podstawowych typów kultury politycznej: parafialnej, poddańczej i uczestniczącej (Almond, Verba, 1963). Jako przeciwwagę dla „klasycznego” modelu kultury obywatelskiej (określanej jako „lojalna” - allegiant culture) w ostatnich latach wprowadzono kategorię asertywnej kultury obywatelskiej (assertive culture, Dalton, Welzel, 2014). Celem niniejszego artykułu jest odpowiedź na pytanie o możliwości opisania współczesnych ruchów protestu za pomocą kategorii asertywnej kultury obywatelskiej. Innymi słowy jest to pytanie o przydatność dotychczasowej definicji kultury obywatelskiej do zobrazowania przeobrażeń zachodzących we współczesnej sferze publicznej, a w szczególności,
\end{abstract}

The "civic culture" is one of the concepts used to describe contemporary socio-political reality. The "classical" civic culture is defined as a combination of three basic types of political culture: parochial, subject and participant (Almond \& Verba, 1963). As a counterweight to this approach, the category of assertive civic culture has been introduced (Dalton \& Welzel, 2014). The aim of this article is to answer the question about the possibility of describing contemporary protest movements using the category of assertive civic culture.

In other words, it is a question of the usefulness of the current definition of civic culture in describing transformations taking place in the contemporary public sphere, and in the area of grassroots social activity in particular. The conducted analyses allow to agree with the thesis about the need to redefine the "classical" definition of civic culture towards an assertive model, with an

* Uniwersytet Marii Curie-Skłodowskiej w Lublinie, Wydział Politologii i Dziennikarstwa. 
w obszarze oddolnej aktywności społecznej. Przeprowadzone analizy pozwalają zgodzić się $\mathrm{z}$ tezą mówiącą o potrzebie redefinicji „klasycznej" definicji kultury obywatelskiej w kierunku modelu asertywnego, z zastrzeżeniem dotyczacym zaufania pomiędzy członkami opisywanych ruchów. Punktem odniesienia dla postawionego $\mathrm{w}$ artykule problemu są ruchy protestu, będące od kilku lat coraz częstszym „aktorem” w przestrzeni publicznej.

Słowa kluczowe: asertywna kultura obywatelska; ruchy protestu; ruchy oddolne exception regarding trust between the members of the described movements. The reference point are in the article the protest movements that have been an increasingly common "actor" in public space for several years.

Keywords: assertive civic culture; protest movements; grassroots movements

\section{WPROWADZENIE}

Kategoria kultury obywatelskiej stanowi jedno z pojęć służących do opisu współczesnej rzeczywistości społeczno-politycznej. W ujęciu klasycznym (civic culture) jest ona definiowana jako swego rodzaju kombinacja trzech podstawowych typów kultury politycznej: parafialnej, poddańczej i uczestniczacej (Almond, Verba, 1963), ale także, co podkreśla m.in. Jerzy Wiatr, jako takie połączenie tych trzech typów kultury politycznej, w którym prymat wiedzie tzw. kultura uczestnicząca: „Kultura obywatelska (ang. civic culture) to kultura uczestnicząca, w której elementy parafialnej kultury politycznej i poddańczej kultury politycznej nie zostały całkowicie usunięte, ale włączone w kulturę polityczną. Obywatele zachowują bardziej tradycyjne ich cechy. Jest najbardziej charakterystyczna dla systemów demokratycznych (Wiatr, 1999)"1.

W ostatnich latach mamy jednak do czynienia z próbami redefinicji tej kategorii. Jako swoistą przeciwwagę dla „klasycznego” modelu kultury obywatelskiej (określanej jako „lojalna” - allegiant culture) wprowadzono kategorię asertywnej kultury obywatelskiej (assertive culture). Charakteryzuje się ona m.in. niskim

1 Kultura obywatelska bywa także określana mianem „wspólnoty obywatelskiej” - „civic community” (Putnam, 1995), „cnót obywatelskich” - „civic virtues” (Kymlicka, 1998) lub też „cnót liberalnych”- „liberal virtues” (Galston 1999). Celem artykułu nie jest jednak pełna rekonstrukcja istniejących w tym zakresie stanowisk badawczych, w związku z czym w tekście przywołane i opisane jest jedynie podejście, które staje się podstawą i punktem wyjścia do dalszych przeformułowań i analiz, czyli podejście „klasyczne”. 
zaufaniem do instytucji, a także silnym poparciem dla zasad demokracji liberalnej przy jednoczesnej niskiej akceptacji dla jej praktyki (Dalton, Welzel, 2014).

Jednocześnie w ostatnich latach jesteśmy świadkami coraz częstszych „wystąpień" społecznych: manifestacji, długotrwałych protestów, a także zajmowania i okupacji przestrzeni miejskich. Szczególna ich intensyfikacja miała miejsce w ostatnim dziesięcioleciu, m.in. pod postacią tzw. arabskiej wiosny w latach 2010-2012, ruchu Occupy zainicjowanego w Stanach Zjednoczonych jesienią 2011 r., wystąpień w Grecji w latach 2010-2012, ruchu Indignados oraz fali społecznych protestów w Hiszpanii w latach 2011-12, wystąpień „oburzonych” we Włoszech i Londynie w 2011 r., krwawych protestów na Ukrainie w 2013 r. czy masowych ruchów protestu wobec umowy ACTA w Polsce w 2012 r. ${ }^{2}$ Można zatem postawić pytanie, na ile zredefiniowana kategoria kultury obywatelskiej jest w stanie opisać i odzwierciedlić przemiany dokonujące się w ramach dzisiejszych społecznych aktywności i aktów niezadowolenia.

Celem niniejszego artykułu jest odpowiedź na pytanie o potencjał kategorii asertywnej kultury obywatelskiej w zakresie opisania współczesnych ruchów protestu. Postawiony problem główny dotyczy zatem eksplanacyjnej mocy ujęcia proponowanego przez Almonda i Verbę i koncentruje się na pytaniu o przydatność propozycji tych autorów do opisu omawianego zjawiska. Towarzyszy mu założenie o potrzebie redefinicji klasycznego modelu kultury obywatelskiej w kierunku modelu asertywnego, który lepiej oddaje kształt dzisiejszej aktywności obywatelskiej oraz procesów dokonujących się w jej ramach. Punktem odniesienia w prowadzonych analizach będą społeczne, oddolne ruchy protestu, będące od kilku lat coraz częstszym „aktorem” w przestrzeni publicznej, a w szczególności przypadek Ogólnopolskiego Strajku Kobiet ${ }^{3}$. Artykuł składa

2 Fale protestów mają także miejsce pod koniec drugiej dekady XXI w., m.in. Wenezueli (od 2014 roku), w Serbii (od 2018 roku), a także we Francji (od grudnia 2018 roku).

${ }^{3}$ Wybór tego przypadku podyktowany był kilkoma względami. Po pierwsze, była to pierwsza od wielu lat manifestacja w Polsce, która wzbudziła tak ogromne zainteresowanie - a co za tym idzie udział przedstawicieli różnych grup społecznych (zob np. analizy opublikowane w pracy zbiorowej dotyczącej Strajku Kobiet: Korolczuk: Kowalska, Ramme, Snochowska-Gonzalez, 2018). Po drugie, owa mobilizacja społeczna nie dotyczyła jedynie dużych miast. Protesty organizowane były także w małych miejscowościach, w których bardzo często były one pierwszą aktywnością obywatelską ich organizatorów i organizatorek (zob. np. Piotrowski, Muszel, 2019). Po trzecie, dla osób zaangażowanych w organizację protestów często był to pierwszy rodzaj obywatelskiej aktywności, który podjęły w swoim życiu (zob. np. Król, Pustułka, 2018). Stąd wydaje się, iż ranga i znaczenie Ogólnopolskiego Strajku Kobiet znacznie przekraczają inne dotychczasowe protesty w Polsce, co wpływa na potrzebę analizy tego przypadku. W artykule korzystam z licznych zrealizowanych już badań empirycznych dotyczących tego ruchu, jak również z opracowań teoretycznych. 
się z czterech części. W pierwszej przypominam wybrane teoretyczne ujęcia współczesnych ruchów protestu. Część druga poświęcona jest rekonstrukcji propozycji Daltona i Welzela, czyli pojęcia asertywniej kultury obywatelskiej. W części trzeciej zaprezentowany został case study - przykład Ogólnopolskiego Strajku Kobiet - ruchu protestu o zasięgu krajowym i międzynarodowym. Część ostatnia, czwarta, stanowi podsumowanie i zaprezentowanie wniosków z przeprowadzonych analiz.

\section{WSPÓŁCZESNE RUCHY PROTESTU}

W 2015 r. redaktorzy książki O kulturze protestu jako rdzeniu tradycji europejskiej pisali: „W przeciwieństwie do wcześniejszych, historycznych kryzysów i upadków systemów politycznych w Europie w tej chwili nie widać na horyzoncie masowych ruchów protestu, które wskazywałyby możliwą alternatywę i drogę do upragnionej Utopii. I to jest największy problem współczesności. (...) Bez pociągającej obietnicy lepszego świata, trudno wyzwolić ludzkie emocje i dokonać społecznej mobilizacji. Wtedy pozostaje tylko coraz bardziej pozbawiona wrażliwości, empatii i pomysłów na nowe wyzwania real politics." (Żuk, 2015, s. 9). Podobny sceptycyzm co do społecznej aktywności i zainteresowania sferą publiczną oraz decyzjami w jej ramach podejmowanymi pojawiał się także w pracach innych badaczy (np. Nowak i Nowosielski, 2006). Nie jest on zresztą specyfiką wyłącznie polską. Istotną cezurę w sposobie postrzegania możliwości przekształceń systemu stanowiły w ubiegłym stuleciu wydarzenia roku 1968 we Francji, efektem których było m.in. pojawienie się głosów o rozczarowaniu ideałami „rewolucyjnymi” i niemożliwością zmiany coraz silniejszego i ugruntowującego swoją pozycję systemu kapitalistycznego (Baudrillard, 2006, s. 6). ${ }^{4}$ Najbardziej skrajną ocenę wynikającą z rozczarowania nikłymi efektami studenckich protestów zaprezentował jeden z największych sceptyków XX w., francuski filozof i socjolog Jean Baudrillard, pisząc m.in. o „społecznych masach” i „milczącej większości”. Bierność, czy nawet pewnego rodzaju bezwład, zniechęcenie, wycofanie, wydają się - wg Francuza - główną determinantą zachowań przedstawicieli współczesnych społeczeństw. Jednocześnie żadne formy oporu czy scenariusze rewolucji wobec dominującego systemu neoliberalnego nie są

4 Por. np. Judt (2013). 
już de facto możliwe do realizacji, każda $\mathrm{z}$ nich zostanie bowiem zawłaszczona przez opresyjny system.

Pojawia się jednak pytanie, czy - szczególnie w kontekście wspomnianych już „rewolucji” z lat 2010-2013 - te dość pesymistyczne opinie są nadal aktualne. Mimo wszystko znaczenie ruchów społecznych ${ }^{5}$, w tym także interesujący nas kontekst ruchów protestu, jest stale eksplorowany przez badaczy podejmujących tę tematykę zarówno na gruncie teoretycznym, jak i badań empirycznych. Do głównych cech tego rodzaju ruchów zaliczają oni m.in. decentralizację, brak struktur, hybrydowość i nieokreśloność, swoistą polifoniczność, a także etyczne i moralne pobudki działań, sytuowane ponad kwestiami legalności, oraz rezygnację ze strategii i planu działań na rzecz elastyczności i spontaniczności (Nowosielski, 2011, s. 18). Badacze wskazują także na najczęściej stosowane techniki i strategie protestu, takie jak okupacja i zajmowanie przestrzeni publicznych (Chodak, 2016), główne źródła i motywy aktywności ruchów (Krastew, 2015), analizują ich przebieg i zróżnicowanie (Mason, 2013), a także pytają o ich ideologiczność (Offe, 2014) lub relacje do innych ruchów społecznych (Castells, 2013). Szczegółowego i wartego odnotowania przeglądu zjawiska w oparciu o istniejące teorie i badania ruchów protestu dokonuje Maciej Kowalewski, podnosząc m.in takie kwestie, jak: opór jako cecha dystynktywna ruchu protestu, konwencjonalność podejmowanych działań, protest jako obszar konfliktu oraz realizacji stosunku władzy, dyskursywność protestów, ich hybrydowość, nietrwałość i amorficzność, a także usytuowanie pomiędzy racjonalnością a emocjonalnością, czy podmiotowość aktorów protestu (Kowalewski, 2016, s. 7-28) ${ }^{6}$.

W niniejszym artykule korzystam z definicji, która, jak sądzę, w najbardziej przejrzysty sposób prezentuje dystynktywne cechy ruchu protestu. Będzie to

${ }^{5}$ Do głównych ujęć teoretycznych ruchów społecznych badacze zjawiska zaliczają cztery podejścia: strukturalny funkcjonalizm, interakcjonizm symboliczny, teorię racjonalnego wyboru oraz tzw. teorię nowych ruchów społecznych (zob np. Mandes, 2007, s. 2-4). W związku z tym, iż celem artykułu nie jest rekonstrukcja przedstawionych podejść, nie dokonuję ich szczegółowego opisu. Warto jedynie zwrócić uwagę na czwarty, ostatni ze wskazanych paradygmatów, czyli na teorię nowych ruchów społecznych. Można bowiem zaryzykować tezę, iż jest ona obecnie najbardziej popularną i najczęściej wykorzystywaną perspektywą do badania omawianego tu zjawiska. Zob np. Touraine (1977), Offe (2005), Castells (1982, 2013).

${ }^{6} \mathrm{~W}$ kontekście omawianego problemu należy także podkreślić, iż ruchy protestu stanowią, szczególnie w ostatnich latach, istotną egzemplifikację wspomnianych nowych ruchów społecznych, m.in. ze względu na przyjętą formę działania. Tym samym protest staje się jednym z głównych wyznaczników i sposobów działania współczesnych ruchów społecznych: „Nie jest już możliwe opisywanie polityki protestu, oddolnej partycypacji oraz symbolicznych wyzwań jako 'niekonwencjonalnych"' (della Porta, Diani, 2009; Mandes, 2007). 
zatem „forma aktywności politycznej obywateli, która (a) ma miejsce głównie poza zinstytucjonalizowanymi kanałami politycznymi; (b) obejmuje przedstawianie decydentom politycznych roszczeń dotyczących różnych kwestii polityki publicznej, których częściowa lub całkowita realizacja wpłynie znacząco na rezultaty tej polityki oraz (c) z zasady wyklucza stosowanie skrajnych form przemocy" (Bajer, 2011, s. 70). Dodatkowo ruch protestu będzie posługiwał się niekonwencjonalnymi formami działania, takimi jak bojkoty, demonstracje, blokady czy okupacje przestrzeni publicznych (Bajer, 2011, s. 66).

\section{ASERTYWNA KULTURA OBYWATELSKA}

Pojęcie kultury obywatelskiej zostało rozpowszechnione w naukach społecznych w 1963 r. przez Gabriela Almonda i Sidney Verbę w pracy Civic Culture: Political Attitudes and Democracy in Five Nations, analizującej zjawisko kultury politycznej (Almond, Verba, 1963)7. Była ona definiowana jako „Szczególna orientacja polityczna - postawy wobec systemu politycznego i jego różnych części i postawy wobec roli jednostki w systemie" (Almond, Verba, 1963, s. 12), czyli innymi słowy jest to „całokształt indywidualnych postaw i orientacji politycznych uczestników danego systemu" (Almond, Powell, 1966, s. 50).

Autorzy wprowadzili trzy główne typy kultury politycznej, tj. kulturę zaściankowa, określaną także jako parafialna (parochial), kulturę podporzadkowania (subject) oraz kulturę uczestnictwa (participant) (Almond, Verba, 1963, s. 16). Niejako na „styku” tych trzech podstawowych typów kultury politycznej umieścili Almond i Verba kulturę obywatelska (civic culture). Jest ona definiowana jako swego rodzaju kombinacja trzech podstawowych typów kultury politycznej (parafialnej, podporzadkowania i partycypacyjnej), w której dominującą rolę odgrywa kultura uczestnictwa. Nie oznacza to jednak, że pozostałe dwa typy, tj. kultury parafialna i podporządkowania, zostały z niej całkowicie usunięte: poszczególne ich elementy nadal mogą się w jej ramach pojawiać. Jednak naczelną rolę będzie tu odgrywała zaangażowana kultura uczestnictwa. $\mathrm{W}$ tak rozumianej kulturze obywatelskiej istotną rolę odgrywać będzie m.in. zaufanie - zarówno na poziomie indywidualnym/personalnym (zaufanie do przedstawicieli grupy), ale

7 Na gruncie krajowym pojęcie to pojawiło się już na początku XX w. Zostało ono użyte przez Józefa Siemieńskiego w artykule pt. „Polska kultura polityczna wieku XVI” i było definiowane jako „najwyższa forma rządów” wytworzona przez określony naród (Siemieński, 1932). 
także instytucjonalnym, czyli wiara w mechanizmy i reguły kierujące systemem politycznym (np. demokratyczne wybory czy zasada przedstawicielstwa/reprezentacji) oraz normy i zasady prawa regulujące ogół relacji społecznych oraz instytucjonalnych. Poza zaufaniem istotnym elementem kultury obywatelskiej jest również wiedza na temat działania mechanizmów systemu demokratycznego, a także chęć uczestnictwa w demokratycznych procedurach (przede wszytym wyborach powszechnych) (Almond, Verba, 1963) ${ }^{8}$.

Należy jednak zwrócić uwagę, że nie jest to jedyny możliwy „wektor” wyznaczony przez definicje kultury obywatelskiej. W drugiej dekadzie XXI w. Dalton i Welzel zaproponowali wyodrębnienie w ramach obywatelskiej kultury politycznej dwóch zasadniczych orientacji: lojalnej (allegiance) oraz asertywnej (assertive). Głównym czynnikiem warunkującym wyodrębnienie tych dwóch podejść stała się koncepcja wartości postmaterialistycznych Ronalda Ingleharta. Wskazywał on na dokonujące się po drugiej wojnie światowej w demokracjach tzw. krajów zachodnich procesy społecznej modernizacji, prowadzące m.in do zwrotu w stronę tzw. wartości postmaterialistyczych. Szczególnie akcentował on

8 Analizy podejmujące omawianą problematykę można także odnaleźć w pracach wspomnianych już Putnama, Kymlicki czy Galstona. Wśród podejmowanych w tym obszarze tematów wskazać można ponadto m.in. kwestie wzmacniania społecznego zaangażowania i kultury obywatelskiej przez władze lokalne (zob np. Andrews, Cowell, Downe, 2008); relacji pomiędzy określonymi wartościami „obywatelskimi” a decyzjami wyborczymi oraz rolą otoczenia instytucjonalnego w tym obszarze (zob np. Jackman, Miller, 2004); wzajemnych oddziaływań kultury obywatelskiej i religii (zob. np. Richard, Regan, 1988); analizujące kulturę obywatelską w odniesieniu do uwarunkowań historycznych i politycznych, w szczególności jej kondycji w krajach byłego „bloku socjalistycznego” (np. Janmaat, 2006; Webber, Liikanen, ed., 2001); wpływu kultury obywatelskiej imigrantów na kulturę kraju „docelowego” (zob. Rice, Feldman, 1997). W odróżnieniu od światowej literatury przedmiotu na gruncie krajowym kategoria kultury obywatelskiej wykorzystywana jest dość rzadko i ustępuje pola szerzej rozumianej kulturze politycznej lub też pojawia się jako jej element, zob. np. artykuły zamieszczone w publikacji „Kultura polityczna jako przedmiot badań” (Sarnacki red., 2016). W nielicznych wyjątkach odnoszona bywa także do kategorii obywatelstwa oraz do badań empirycznych w tym zakresie (zob. Sekuła, 2009). W drugiej połowie XX w. badania nad kulturą obywatelską kontynuowali w Polsce m.in. Jerzy Wiatr czy Edmund Wnuk-Lipiński. O ile Wiatr podkreślał rolę i prymat kultury uczestniczącej w tworzeniu kultury obywatelskiej (zob. Wiatr, 1999), o tyle Wnuk-Lipiński zaproponował odmienny model kultury obywatelskiej. W jego propozycji kultura obywatelska jest kategorią skupiającą w sobie „zarówno polityczne, jak i apolityczne aktywności obywatela”. A zatem jest to zarówno działanie stricte polityczne (udział w wyborach powszechnych, demonstrowanie poglądów i „sympatii” politycznych, inicjatywa obywatelska oraz wszelkie inne działania realizowane w obszarze polityki), jak też aktywności związane z tzw. „rolą obywatelską” (działalność w wolontariacie, organizacjach pozarządowych czy szeroko rozumiany aktywizm społeczny) (Wnuk-Lipiński, 2008, s. 160-162). 
znaczenie: indywidualizmu, roli jakości życia, autoekspresji i poczucia przynależności, a także praw człowieka, wolności słowa czy dążenia do wpływu na władze oraz podejmowane przez nie decyzje, przejawiające się m.in. powstawaniem nowych ruchów społecznych (Inglehart, 1977, 2006, s. 334-348).

Analizując wydarzenia $\mathrm{z}$ drugiej połowy XX w. (jak chociażby studenckie manifestacje we Francji pod koniec lat 60. czy liczne manifestacje lat 70. wymierzone m.in. przeciwko wojnie w Wietnamie itp.), a także biorąc pod uwagę koncepcję wartości postmaterialistycznych Ingleharta, Dalton i Welzel analizują rosnące znaczenie ruchów społecznego protestu i kontestacji wymierzonych m.in w wąskie i elitarne kręgi sprawujące władzę oraz w sposób realizowania przez te grupy idei demokracji. Wskazują oni jednocześnie, że tego rodzaju działania (manifestacje, strajki, blokady czy okupowanie budynków użyteczności publicznej - placów, uniwersytetów itp.) nie mają na celu podważania zasad demokracji. Stanowią one bowiem wyraz społecznego zaangażowania w rzeczywistą realizację jej idei, takich jak „obywatelska partycypacja, wolność ekspresji oraz zobowiązanie elit do odpowiadania na publiczne oczekiwania”. Stwierdzają także, iż „Protestujący z lat 60. i 70. zdawali się przewidywać nowy model asertywnego obywatela demokratycznego, który kontrastuje z lojalnym modelem kultury obywatelskiej" (Dalton, Welzel, 2014, s.7).

W ujęciu proponowanym przez Daltona i Welzela „klasyczna” obywatelska kultura polityczna opisana przez Almonda i Verbę ma w rzeczywistości wymiar kultury lojalnej, co stwierdzili de facto sami autorzy koncepcji jeszcze w latach 60.: "the civic culture is an allegiant participant culture" (Almond, Verba, 1963, s. 30; Dalton, Welzel, 2014, s. 6), czyli „kultura obywatelska jest lojalną kulturą uczestniczącą”. Lojalna kultura obywatelska odznacza się zatem takimi właściwościami, jak: szacunek i uznanie dla władzy przejawiający się w każdym obszarze życia, tj. w życiu rodzinnym (szacunek dla „głowy rodziny”), zawodowym oraz w sferze publicznej; respektowanie jej decyzji oraz podążanie w wyznaczonym przez nią kierunku zamiast obywatelskiego wytyczania nowych dróg i możliwości działania; zorientowanie na porządek oraz bezpieczeństwo, które wyznaczają (ale jednocześnie ograniczają) zakres wypowiedzi i uczestnictwa jednostek w sferze publicznej; wysoki poziom zaufania społecznego, zarówno na poziomie indywidualnym, ale także społecznym czy instytucjonalnym; wspieranie i umacnianie zasad i procesów demokratycznych; ograniczona akceptacja dla obywatelskiego nieposłuszeństwa, główna aktywność polityczna obywateli sprowadzona do głosowania oraz innych „konwencjonalnych form legitymacji” władzy; idea demokracji realizowana poprzez możliwość zabierania 
głosu i wypowiedzi w sprawach społecznie istotnych oraz współuczestnictwo w procesach decyzyjnych (Dalton, Welzel, 2014, s. 7-11) .

Opisywane przez Daltona i Welzela przekształcenia modelu kultury obywatelskiej będą zmierzały w kierunku orientacji asertywnej. Badacze stwierdzają, iż warunkiem zapewniającym względną trwałość i stabilność systemu demokratycznego nie jest już (lojalna) kultura obywatelska definiowana w sposób zaproponowany przez Almonda i Verbę. Jej miejsce zajęła bowiem, będąca do pewnego stopnia jej zaprzeczeniem, kultura asertywna.. O ile w przypadku lojalnej kultury obywatelskiej główną ramą konstruującą i „utrzymującą” system był ład i bezpieczeństwo publiczne, o tyle dla asertywnie ukierunkowanej kultury obywatelskiej naczelne stają się kwestie związane z możliwością publicznego „zabrania głosu” oraz partycypacji - nawet kosztem priorytetów związanych z porządkiem i bezpieczeństwem. Mamy zatem do czynienia ze znacznym zwiększeniem dystansu społecznego w różnych obszarach funkcjonowania, zarówno w stosunku do władz, ale także na poziomie mikro i mezospołecznym (w miejscu pracy czy w ramach grup pierwotnych, jak np. rodzina). Badacze wskazują również na cechujące asertywnie zorientowaną kulturę obywatelska silne poparcie dla idei oraz zasad demokracji, ale jednocześnie towarzyszący im sprzeciw wobec sposobów ich praktycznego urzeczywistniania (tzw. niezadowoleni demokraci). Podejście to podkreśla również dominującą rolę aktywnego uczestnictwa $\mathrm{w}$ sferze polityki oraz działań związanych $\mathrm{z}$ artykułowaniem potrzeb i proponowaniem rozwiązań, które miałyby zastąpić postawy oparte na biernym oczekiwaniu na wprowadzenie określonych rozstrzygnięć. Będzie to zatem czynny udział w szeroko rozumianej sferze polityki, przejawiający się nie tylko dążeniem do partycypacji oraz do realnego wpływu na procesy decyzyjne, zainicjowane przez władze (na poziomie lokalnym lub krajowym), ale także ich oddolne, społeczne aranżowanie. Będą to więc działania mieszczące się dotychczas w ramach lojalnej kultury obywatelskiej (na przykład udział w konsultacjach i panelach obywatelskich, debatach oraz spotkaniach z przedstawicielami władz, przekazywanie uwag oraz propozycji rozwiązań i rekomendacji, prowadzenie akcji społecznych w mediach społecznościowych czy działalność organizacji pozarządowych, oparta na przygotowywaniu i realizacji projektów). Jednak takie formy działania coraz częściej uzupełniane są aktywną działalnością w zakresie

9 Egzemplifikacją analiz dotyczących kultury obywatelskiej są zwykle dane ze Światowego i Europejskiego Badania Wartości (World/European Values Survey), zob. Janmaat (2006). 
organizowania akcji protestacyjnych, demonstracji bądź „okupacji” miejsc użyteczności publicznej (Jakobsen i Listhaug, 2014, s. 219-230)

Asertywna kulturę obywatelską będą również charakteryzowały takie działania, jak ujawnianie krytycznej postawy oraz dawanie wyrazu społecznym obawom i niezadowoleniu $\mathrm{z}$ decyzji politycznych bądź z naruszania praw określonych grup społecznych, a także nacisk na udział obywateli (na różnych szczeblach) w podejmowaniu decyzji dotyczących wspólnoty. Innymi słowy, asertywna kultura obywatelska będzie wprowadzać do „głównego nurtu” kwestie dotychczas nieobecne lub podejmowane niezwykle rzadko, ukierunkowanie na wartości emancypacyjne, takie jak egalitaryzm, możliwość swobodnej ekspresji własnych poglądów i przekonań, podkreślanie znaczenia równych szans i możliwości oraz wolności i praw zarówno indywidualnych (np. zespół tzw. praw reprodukcyjnych), jak też wspólnotowych. Będzie to również silne przekonanie, że różnice pomiędzy poszczególnymi grupami społecznymi, w tym w szczególności różnice wynikające z płci, rasy, pochodzenia etnicznego czy orientacji seksualnej, nie uzasadniają nierównych szans w dostępie do edukacji, zatrudnienia czy w sferze polityki, a naruszenie zasady równych praw będzie skutkowało społeczną dezaprobatą oraz podejmowaniem działań zbiorowych (strajków, protestów etc.).

\section{RUCHY PROTESTU JAKO WYRAZICIELE ASERTYWNEJ KULTURY OBYWATELSKIEJ}

Wstępne ustalenia dotyczące ruchów protestu, jak również kategorii asertywnej kultury obywatelskiej wskazują na konieczność zadania pytania o jej użyteczność do opisu omawianego zjawiska, czyli ruchów protestu. Jako case study do niniejszego artykułu wybrany został Ogólnopolski Strajk Kobiet - masowy ruch protestu z 2016 r ${ }^{10}$. Ogólnopolski Strajk Kobiet, a także leżące u źródeł jego powstania tzw. czarne protesty były reakcją na zapowiedź podjęcia przez Sejm

10 Inne ruchy protestu w Polsce to m.in ruch przeciwko umowie ACTA, Komitet Obrony Demokracji, jak również szereg lokalnych protestów i społecznych wystąpień, zob. np. Kowalewski (2016). Narzędzie, jakim jest protest, nie jest przypisane wyłącznie ruchom społecznym, może ono również zostać wykorzystane przez innych uczestników debaty publicznej, np. organizacje pozarządowe, związki zawodowe czy partie polityczne. 
RP prac nad projektem ustawy o całkowitym zakazie aborcji ${ }^{11}$ oraz jednoczesne odrzucenie tzw. projektu społecznego łagodzącego prawo antyaborcyjne. Był to zatem masowy, oddolny i społeczny protest będący głosem sprzeciwu wobec realnej perspektywy zaostrzenia prawa w tym zakresie ${ }^{12}$.

Główny masowy protest, będący swojego rodzaju „początkiem” ruchu, miał miejsce 3 października 2016 r. i spowodowany był odrzuceniem przez Sejm RP projektu obywatelskiego Ratujmy Kobiety ${ }^{13}$ oraz jednoczesnym skierowaniem do komisji projektu Ordo Iuris „Stop Aborcji”. Pod koniec września 2016 r. w dziewięciu miastach Polski odbyły się masowe demonstracje organizowane przez Partię Razem pod hasłem „czarny protest” (\#czarnyprotest). Pojawiła się także idea zorganizowania masowego, ogólnopolskiego „strajku” kobiet, ${ }^{14}$ który odbył się w poniedziałek 3 października 2016 r. (tzw. Czarny Poniedziałek). W masowych protestach i marszach w 150 miastach Polski wzięło udział ok. 200 tysięcy osób. Dodatkowym elementem protestu była jego strona symboliczna, tj. czarny ubiór oraz/lub absencja w miejscu pracy (strajk). Efektem ogólnopolskiej fali protestów było zaprzestanie przez Sejm RP prac nad propozycją zaostrzenia prawa antyaborcyjnego, a także uformowanie się wspomnianego już ruchu Ogólnopolski Strajk Kobiet. O skali i zasięgu protestu świadczył jego masowy charakter. Jak zauważają badacze opisujący zjawisko: „Nie [jest to - A.Z] ekskluzywny ruch kobiet z klasy średniej, z wielkomiejskich elit, ale ogólnokrajowa, a następnie również międzynarodowa, mobilizacja kobiet w kilku krajach świata, na rzecz naszych praw” (Majewska, 2016). „Ogromnym sukcesem, a jednocześnie owego sukcesu warunkiem, okazała się różnorodność ruchu. Choć największe manifestacje wiosną i jesienią odbyły się w dużych miastach (Kraków, Łódź, Warszawa i Wrocław), to lokalne protesty zorganizowano w ponad 140 miastach i wsiach w całej Polsce: w strajku wzięły udział m.in. pracownice Delikatesów w Łazach, sklepu odzieżowego w Wejherowie, studia paznokci na Pradze Północ

11 Projekt ustawy został złożony do Sejmu RP jesienią 2016 r. przez Instytut na rzecz Kultury Prawnej Ordo Iuris.

12 Od wyborów parlamentarnych w 2015 r. większość w Sejmie posiadało Prawo i Sprawiedliwość, w związku z czym z dużym prawdopodobieństwem można było zakładać, iż prace nad ustawą mogłyby, przy braku społecznego sprzeciwu, zakończyć się uchwaleniem bardzo restrykcyjnego prawa w zakresie dopuszczalności przerywania ciąży.

13 Projekt złożony przez grupę aktywistek i działaczy społecznych, zob. https://www.dropbox. com/s/y3m0j7fc9elzjmy/ProjektRatujmy2017final-2.pdf?dl=0 , data dostępu: 15 marca 2019.

${ }^{14}$ Wzorem stał się islandzki „strajk kobiet” z 1975 roku, który polegał na powstrzymaniu się przez kobiety od pracy zawodowej i wykonywania obowiązków domowych, co miało na celu podkreślenie wartości pracy kobiet. 
czy starostwa w Kluczborku; demonstracje i pikiety pojawiły się też w wielu miastach na świecie (m.in. w Berlinie, Londynie, Nowym Jorku i Sztokholmie).” (Korolczuk, 2017).

„Czarny Poniedziałek”, a także będący jego pokłosiem Ogólnopolski Strajk Kobiet stanowiły masowy, społeczny, a przede wszystkim nieformalny ruch oddolny, którego głównym celem było zamanifestowanie i obrona fundamentalnych praw społecznych. Chodziło zatem o emancypacyjne zademonstrowanie poparcia dla określonych wartości istotnych dla uczestników protestów (wolność wyboru, prawo do samostanowienia), a także żądanie uwzględnienia zgłaszanych postulatów.

Należałoby w tym miejscu postawić pytanie o adekwatność kategorii asertywnej kultury obywatelskiej do przykładu, jakim jest Ogólnopolskie Strajk Kobiet. W tym celu konieczne jest przywołanie poszczególnych aspektów kultury asertywnej wskazanej przez Daltona i Welzela, które oddają specyfikę omawianego ruchu. Można wskazać co najmniej trzy, będące istotą asertywnej kultury obywatelskiej.

Po pierwsze, są to wspomniane wartości postmaterialistyczne, w szczególności te o charakterze emancypacyjnym (m.in. potrzeba „zabierania głosu”, wyartykułowania swojego stanowiska, „bycia usłyszanym” w ważnych sprawach, dotyczących samych zainteresowanych, a także egzekwowanie prawa do samostanowienia, do samodzielnego decydowania m.in. w kwestii praw reprodukcyjnych, do zamanifestowania swoich poglądów, zaznaczenia odmiennego punktu widzenia). Niewątpliwie są one widoczne w omawianych w artykule działaniach. Jak pisze jedna z uczestniczek i komentatorek Strajku: „Sprawy dotyczące kobiet przez ostatni rok weszły na łamy gazet i do telewizji. Ogromne i żywe grupy kobiece na Facebooku pokazały, jak bardzo tego brakowało: każdy news zaczął się roznosić z prędkością światła. Okazało się, że polskie kobiety mają dość czytania o wirtualnym kraju, w którym niemal wszyscy chodzą w garniturach i najbardziej martwią się cenami paliw. Media zaczęły się dostosowywać" (Czarnacka, 2017).

Po drugie, protesty podejmowane w ramach Ogólnopolskiego Strajku Kobiet wypełniają przesłanki asertywnej kultury obywatelskiej także w zakresie krytycznej postawy wobec władzy, w tym także ograniczonego zaufania do podejmowanych przez nią decyzji i działań (tzw. orientacja wobec autorytetu oraz zaufanie instytucjonalne). Podkreślały to same uczestniczki Strajku Kobiet, zarówno poprzez hasła rozpowszechniane na demonstracjach („Beata, niestety, Twój rząd obalą kobiety”), ale także w wygłaszanych przemówieniach: 
„Obywatelki! (...) Mamy dość i powinnyśmy zacząć brać sprawy w swoje ręce, dlatego dzisiaj apeluję, proszę, zastanówcie się. Mamy rok wyborczy. Stulecie uzyskania praw wyborczych kobiet. Nie pozwólmy odebrać nam władzy. Nie pozwólmy, żeby ktoś decydował za nas. Czas najwyższy, abyście uwierzyły, uświadomiły sobie, że to wy wiecie, jak rozwiązywać problemy, że to wy szukacie rozwiązania konfliktów, bo to wy dajecie sobie ze wszystkim radę" (Nawojski, Ramme, 2019). W przypadku Ogólnopolskiego Strajku Kobiet mamy także do czynienia z w pełni oddolnym, spontanicznym i społecznym ruchem, z działaniem niezinstytucjonalizowanym, wykraczającym poza dotychczasowe ramy tzw. „trzeciego sektora”, co również uznać można za przejaw ograniczonego zaufania instytucjonalnego.

Jedna z cech podejścia proponowanego przez Daltona i Welzela dotyczy również sposobu rozumienia demokracji („poparcie demokratyczne” oraz „pojmowanie demokracji”). Zgodnie z ideą asertywnej kultury obywatelskiej, w przypadku Strajku Kobiet mamy do czynienia z silnym poparciem dla zasad demokracji (rozumianej m.in. jako możliwość publicznego „zabierania” głosu, uczestnictwa w sferze publicznej, procesach decyzyjnych etc.) przy jednoczesnej krytyce sposobu jej praktycznej realizacji (wspomniany już brak zaufania do władz oraz podejmowanych przez nią działań i decyzji). Strajkujące kobiety reprezentują zatem tzw. „niezadowolonych demokratów”, a zatem co do zasady popierają idee systemu demokratycznego, nie godzą się jednak z praktykami podejmowanymi przez rządzących, które zdaniem protestujących godzą i łamią podstawowe filary demokracji.

\section{WNIOSKI}

Analizując aktywność obywatelską w pierwszych dwóch dekadach XXI w., przejawiającą się m.in. intensyfikacją działań ruchów protestu, można zgodzić się $\mathrm{z}$ tezą o konieczności redefinicji klasycznego rozumienia kultury obywatelskiej. Nie będzie to już zatem kultura w głównej mierze oparta na biernej akceptacji działań i decyzji podejmowanych przez władze (zarówno na poziomie lokalnym, jak i krajowym) oraz dostosowywaniu się do narzucanych odgórnie „zasad gry” i wzorów postępowania. Zasady te coraz częściej stają się bowiem obszarem społecznej „walki” o realizację potrzeb poszczególnych grup społecznych, przy jednoczesnym postrzeganiu sfery polityki jako wypaczenia i karykatury systemu demokracji liberalnej. 
Biorąc pod uwagę wyróżnione przez Daltona i Welzela determinanty asertywnej kultury obywatelskiej oraz zestawiając je z Ogólnopolskim Strajkiem Kobiet, można stwierdzić, iż z jednej strony kategoria asertywnej kultury obywatelskiej oraz opisywane przez nią postawy (w tym przede wszystkim aktywnego i zwerbalizowanego sprzeciwu wobec określonych praktyk rządzących, zanegowania i braku podporządkowania decyzjom podejmowanym przez władze, oporu, a nawet buntu wobec nieuwzględniania społecznych oczekiwań, a także egzekwowania prawa do artykułowania swoich potrzeb w przestrzeni publicznej) wydaje się być propozycją adekwatnie opisującą przekształcenia w ramach form społecznych aktywności oraz udziału w debacie publicznej.

Z drugiej jednak strony liczne przykłady oddolnych ruchów protestu pokazują, że teza o ograniczonym zaufaniu na poziomie mikrospołecznym konstytuującym asertywny wymiar kultury obywatelskiej wydaje się problematyczna. O ile bowiem nieformalna i niezinstytucjonalizowana forma działania dość często wybierana przez ruchy protestu (czy ruchy społeczne w ogóle) może stanowić przejaw szeroko rozumianego zanegowania prawnie usankcjonowanych struktur i form działania, a także braku zaufania do „formalnych” ram funkcjonowania (zob. np. Lewicki, Rogaczewska, Ziętek, 2016), o tyle trudno zgodzić się ze stwierdzeniem ${ }^{15}$, że w ramach asertywnej kultury obywatelskiej mamy do czynienia z zanikiem zaufania społecznego, także na poziomie relacji wewnątrzgrupowych. Jak bowiem wskazują badania, jest ono istotnym elementem stanowiącym podstawę do organizowania się jednostek, tworzenia oddolnych ruchów społecznych, jak również przygotowywania i podejmowania wspólnych działań, w tym także protestów. Innymi słowy zaufanie w tym wymiarze stanowi swego rodzaju spoiwo będące podstawą do wspólnych działań podejmowanych przez członków grupy ${ }^{16}$.

Pomimo tej niezgodności (która stanowić może obszar dalszych dociekań badawczych) propozycja Daltona i Welzela wydaje się adekwatną odpowiedzią na przemiany zachodzące w sferze współczesnej aktywności obywatelskiej, w tym w szczególności w obszarze ruchów protestu.

15 „Niezadowoleni demokraci różnią się jednak od usatysfakcjonowanych demokratów niższym zaufaniem do instytucji, niższym poziomem zaufania interpersonalnego (...)", komentarz Klingemanna na temat asertywnej kultury obywatelskiej (Klingemann, 2014, s. 140).

16 „Grupy nieformalne to sieci działające na zasadzie wzajemnego zaufania, w odróżnieniu od organizacji opartych na z góry określonej strukturze, z jej nieodłącznymi elementami: członkostwem, hierarchią, zasadami, nadzorem i sankcjami” (Polańska, 2015, s. 31); zob. także Bilewicz, Potkańska (2013, s. 37), Sztompka (2017). 
BibLIOGRAFIA:

Almond, G. A., Verba S. (1963). Civic Culture: Political Attitudes and Democracy in Five Nations. Princton: Princeton University Press.

Almond, G.A., Powell, G.B. (1966). Comparative Politics: a Developmental Approach. Boston: Little, Brown and Company.

Andrews, R., Cowell, R., Downe, J. (2010). Promoting Civic Culture By Supporting Citizenship: What Difference Can Local Government Make? Public Administration, 89(2), 595-610.

Bajer, J. (2011). Polityczne ruchy protestu we współczesnym systemie demokratycznym: analiza pojęcia. W: S. Wróbel (red.). Teoretyczne problemy ruchów społecznych i politycznych. Toruń: Wydawnictwo Naukowe Grado.

Baudrillard, J. (2006). W cieniu milczącej większości. Warszawa: Wydawnictwo Sic!

Bilewicz, A., Potkańska, D. (2013), Jak kiełkuje społeczeństwo obywatelskie? Kooperatywy spożywcze w Polsce jako przykład nieformalnego ruchu społecznego. Trzeci sektor, 31(3), 25-44.

Castells, M. (1982). Kwestia miejska. Warszawa: Państwowe Wydawnictwo Naukowe.

Castells, M. (2013). Sieci oburzenia i nadziei. Ruchy społeczne w erze internetu. Warszawa: Wydawnictwo Naukowe PWN.

Chodak, J. (2016). Okupacja przestrzeni publicznej jako taktyka współczesnych ruchów protestu. Przestrzeń społeczna, 1(11), 74-101.

Czarnacka, A. (2017). Po Czarnym Wtorku - czy kobiety przegrały? pobrane z: https:// www.polityka.pl/tygodnikpolityka/spoleczenstwo/1722500,1,po-czarnym-wtorku-czy-kobiety-przegraly.read.

Dalton, R. J., Welzel, Ch. (red.). (2014). The Civic Culture Transformed From Allegiant to Assertive Citizens. Cambridge: University Press.

Dalton, R. J., Welzel, Ch. (2014). Political Culture and Value Change. W: Dalton, R. J., Welzel, Ch. (red.). The Civic Culture Transformed From Allegiant to Assertive Citizens (s. 1-16), Cambridge: University Press.

della Porta, D. Diani, M. (2009). Ruchy społeczne. Wprowadzenie. Kraków: Wydawnictwo Uniwersytetu Jagiellońskiego.

Galston, W. (1999). Cele liberalizmu. Kraków: Wydawnictwo Znak.

Inglehart, R. (1977). The Silent Revolution. Changing Values and Political Styles among Western Publics. Princeton: Princeton University Press.

Inglehart, R. (2006). Pojawienie się wartości postmaterialistycznych. W: P. Sztompka, M. Kucia (red.). Socjologia. Lektury. Kraków: Wydawnictwo Znak.

Jackman, R.W, Miller, R.A. (2004). Before Norms Institutions and Civic Culture. Michigan: The University of Michigan Press.

Janmaat, J.G. (2006) Civic Culture in Western and Eastern Europe. European Journal of Sociology, 47(3), 363-393, DOI:10.1017/S0003975606000129.

Jakobsen, T.G., Listhaug,O. (2014). Social Change and the Politics of Protes. W: R. J. Dalton, Ch.Welzel (red.). The Civic Culture Transformed. From Allegiant to Assertive Citizens (s. 213-239). Cambridge University Press. 
Judt, T., (2013). Historia niedokończona. Francuscy intelektualiści 1944-1956. Warszawa: Wydawnictwo Krytyki Politycznej.

Klingemann, H.D. (2014). Dissatisfied Democrats: Democratic Maturation in Old and New Democracies. W: R. J. Dalton, Ch.Welzel (red.). The Civic Culture Transformed. From Allegiant to Assertive Citizens (s. 116-157). Cambridge University Press.

Kowalewski, M. (2016). Protest miejski. Przestrzenie, tożsamości i praktyki niezadowolonych obywateli miast. Kraków: Wydawnictwo Nomos.

Korolczuk, E., Kowalska, B., Ramme, J., Snochowska-Gonzalez, C. (red.). (2018). Bunt kobiet. Czarne Protesty i Strajki Kobiet. Gdańsk: Europejskie Centrum Solidarności

Koroluczuk, E. (2016). Czarne protesty 2016: skąd się wzięty i czego nas ucza? pobrane z: https://www.researchgate.net/publication/314724410_Czarne_protesty_2016_ skad_sie_wziely_i_czego_nas_ucza.

Krastew, I. (2015). Demokracja: przepraszamy za usterki. Warszawa: Wydawnictwo Krytyki Politycznej.

Król, A., Pustułka, P. (2018). Women on strike: mobilizing against reproductive injustice in Poland. International Feminist Journal of Politics, 20(4), 1-19.

Kymlicka, W. (1998). Wspótczesna filozofia polityczna. Wprowadzenie. Kraków-Warszawa: Wydawnictwo Znak, Fundacja im. Stefana Batorego.

Lewicki, M., Rogaczewska, M., Ziętek, A. (2016). Kultura i rozwój - podsumowanie projektu badawczego. W: J. Hausner, I. Stokfiszewski, I. Jasińska, M. Lewicki (red.). Kultura i rozwój. Analizy, rekomendacje, studia przypadków (s. 79-138). WarszawaKraków: Instytut Studiów Zaawansowanych, Fundacja Gospodarki i Administracji Publicznej.

Majewska, E. (2016). Słaby opór i siła bezsilnych. \#CzarnyProtest w Polsce 2016. Praktyka Teoretyczna, 10. Pobrane z: http://www.praktykateoretyczna.pl/ewa-majewska-slaby-opor-i-sila-bezsilnych-czarnyprotest-kobiet-w-polsce-2016/.

Mandes, S. (2007). Ruchy społeczne w Polsce. W: M. Marody (red.). Wymiary życia społecznego. Polska na przełomie XX i XXI wieku. Warszawa: Wydawnictwo Scholar.

Mason, P. (2013). Skąd ten bunt? Nowe światowe rewolucje. Warszawa: Wydawnictwo Krytyki Politycznej.

Nawojski, R., Ramme, J. (2019). Przemówienia. W: E. Korolczuk, B. Kowalska, J. Ramme, C. Snochowska-Gonzalez (red.). Bunt kobiet. Czarne Protesty i Strajki Kobiet (s. 185-200). Gdańsk: Europejskie Centrum Solidarności.

Nowak, M., Nowosielski M. (red.). (2006). Czy społeczny bezruch? O społeczeństwie obywatelskim i aktywności we współczesny, Poznań: Instytut Zachodni.

Nowosielski, M. (2011). Socjologiczna refleksja na temat ruchów społecznych. Przegląd Zachodni, 4, 3-28.

Offe, C. (2005). Nowe ruchy społeczne, przekraczanie granic polityki instytucjonalnej. W: P. Sztompka, M. Kucia (red.). Socjologia. Lektury (s. 218-224). Kraków: Wydawnictwo Znak.

Offe, C. (2014). Kapitalizm postdemokratyczny, pobrano z: https://krytykapolityczna. $\mathrm{pl} /$ swiat/ue/offe-kapitalizm-postdemokratyczny/. 
Piotrowski, G., Muszel, M. (2019). Rocking the small-town boat: black protest activists in small and provincial polish cities. Praktyka Teoretyczna, 4(30), 89-116.

Polańska, D. V. (2015). Motywacje osób niezinstytucjonalizowanego sektora społecznościowego. W: G. Chimiak, K. Iwińska (red.). Krajobraz społecznościowy - Polska 2014 (s. 27-46). Warszawa: Collegium Civitas i Centrum Wspierania Aktywności Lokalnej CAL.

Putnam, R. D. (1995). Demokracja w działaniu: tradycje obywatelskie we współczesnych Włoszech. Kraków: Wydawnictwo Znak.

Richard, J., Regan, S.J., (1988). Virtue, Religion, and Civic Culture. Midwest Studies In Philosophy, XIII, 342-351.

Rice, T.W., Feldman, J.L. (1997). Civic culture and democracy from Europe to America. Journal of Politics, 59(4), 1143-1172.

Sarnacki, A., J. (red.). (2016). Kultura polityczna jako przedmiot badań. Kraków: Akademia Ignatianum, Wydawnictwo WAM.

Sekuła, P. (2009). Kultura polityczna a konsolidacja demokracji. Kraków: Krakowskie Towarzystwo Edukacyjne sp. z o.o., Oficyna Wydawnicza AFM.

Siemieński, J. (1932). Kultura polityczna wieku XVI. W: Kultura staropolska, Kraków: Polska Akademia Umiejętności, pobrane: http://www.polskietradycje.pl/artykuly/ widok/452.

Sztompka, P. (2007). Zaufanie. Fundament społeczeństwa. Kraków: Wydawnictwo Znak. Touraine, A. (1977). The Self-Production of Society. Chicago: University of Chicago Press. Webber, S., Liikanen, I. (red.). (2001). Education and Civic Culture in Post-Communist Countries. New York: Palgrave Macmillan UK.

Wiatr, J. (1999). Socjologia wielkiej przemiany. Warszawa: Wydawnictwo KAP.

Wnuk-Lipiński, E. (2008). Socjologia życia publicznego. Warszawa: Wydawnictwo Naukowe Scholar.

Żuk, P., Żuk P. (2015). Od utopii do protestu... i dalej poza horyzont status quo. W: P. Żuk, P. Żuk (red.). O kulturze protestu jako rdzeniu tradycji europejskiej (s. 9-16). Warszawa: Instytut Wydawniczy Książka i Prasa. 